Camden After the Fall 
POLITICS AND CULTURE IN MODERN AMERICA

Series Editors

Michael Kazin

Glenda Gilmore

Thomas J. Sugrue

A complete list of books in the series is available from the publisher. 


\section{Camden After the Fall}

Decline and Renewal in a

Post-Industrial City

Howard Gillette, Jr.

$\overline{\text { PENN }}$

University of Pennsylvania Press

Philadelphia 
Publication of this book was assisted by a grant from the Ford Foundation

Copyright (C) 2005 University of Pennsylvania Press

All rights reserved

Printed in the United States of America on acid-free paper

$\begin{array}{lllllllll}10 & 9 & 8 & 7 & 6 & 5 & 4 & 3 & 2\end{array}$

First paperback edition published 2006

Published by

University of Pennsylvania Press

Philadelphia, Pennsylvania 19104-4112

Library of Congress Cataloging-in-Publication Data

Gillette, Howard.

Main Title: Camden after the fall : decline and renewal in a post-industrial city / Howard Gillette, Jr.

p. cm. - (Politics and culture in Modern America)

Includes bibliographical references and index.

ISBN-10: 0-8122-1968-6 (pbk. : alk. paper)

ISBN-13: 978-0-8122-1968-5 (pbk. : alk. paper)

1. Urban renewal-New Jersey-Camden-History. 2. Camden (N.J.)—History.

3. Camden (N.J.)—Politics and government. 4. Camden (N.J.)—Economic conditions.

I. Title. II.

F144.C2 G55 2005

$974.9^{\prime} 87-d c 22$

2005047160 
When it is dark enough, you can see the stars

-Posting, billboard of Hatch Middle School, Camden, May 1998

For Margaret 
